\title{
ANALISIS REGRESI ORDINAL MODEL LOGIT UNTUK MENGIDENTIFIKASI FAKTOR YANG MEMPENGARUHI INDEKS PEMBANGUNAN MANUSIA
}

\section{LOGIT ORDINAL REGRESSION ANALYSIS TO IDENTIFY FACTORS AFFECTING THE HUMAN DEVELOPMENT INDEX}

\author{
Yonita Dyah Puji Dwiningtias', Mahmudah ${ }^{2}$ \\ 1,2Departemen Biostatistika dan Kependudukan \\ Fakultas Kesehatan Masyarakat Universitas Airlangga \\ J1. Mulyorejo Kampus C Unair Surabaya, Jawa Timur 60115, Indonesia \\ Alamat korespondensi: Yonita Dyah Puji Dwiningtias \\ E-mail: yonita.dyah.puji-2015@fkm.unair.ac.id
}

\begin{abstract}
The Human Development Index (HDI) is an index used to determine the level of quality of human life. HDI became a trend because all local governments are competing to increase the value of their regional HDI. This study aims to identify the factors that influence the HDI of districts/cities in East Java Province in 2017 using the logit model ordinal regression approach. This type of research is a non reactive study using secondary data from the Central Statistics Agency and the East Java Province Health Office in 2017. The study population is all districts/cities of East Java Province. The total research analysis unit was 38 districts/cities. The dependent variable of the study is low, medium, high and very high HDI. The independent variable of the study is the percentage of households behaving clean and healthy, student-teacher ratio (high school level) and open unemployment rate. The results of the analysis using the logit model ordinal regression test $(\alpha=5 \%)$ prove there is an influence between the open unemployment rate variable ( $p=0.006 ; \beta=0.790)$ on the HDI. The variable percentage of households behaving clean and healthy and student-teacher ratio (high school level) has no effect on HDI. Both central and regional governments are expected to be able to improve human development in all sectors, especially health, education and the economy.
\end{abstract}

Keywords: ordinal regression, human development index, logit model

\begin{abstract}
ABSTRAK
Indeks Pembangunan Manusia adalah indeks yang dipergunakan untuk menentukan tingkat kualitas hidup manusia. IPM sedang menjadi tren karena seluruh pemerintah daerah berlomba-lomba untuk meningkatkan nilai IPM daerahnya. Penelitian ini memiliki tujuan mengidentifikasi faktor yang menjadi pengaruh bagi IPM kabupaten/ kota Provinsi Jawa Timur tahun 2017 memakai pendekatan regresi ordinal model logit. Jenis penelitian merupakan penelitian non reaktif dengan memakai data sekunder dari Badan Pusat Statistik dan Dinas Kesehatan Provinsi Jawa Timur tahun 2017. Populasi penelitian yaitu semua kabupaten/kota Provinsi Jawa Timur. Total unit analisis penelitian sebanyak 38 kabupaten/kota. Variabel dependen penelitian adalah IPM dengan kategori rendah, sedang, tinggi dan sangat tinggi. Variabel independen penelitian yaitu persentase rumah tangga berperilaku hidup bersih dan sehat, rasio murid-guru (tingkat SMA) dan tingkat pengangguran terbuka. Hasil analisis dengan menggunakan uji regresi ordinal model logit $(\alpha=5 \%)$ membuktikan ada pengaruh antara variabel tingkat pengangguran terbuka $(p$ $=0,006 ; \beta=0,790)$ terhadap IPM. Variabel persentase rumah tangga berperilaku hidup bersih dan sehat serta rasio murid-guru (tingkat SMA) tidak ada pengaruh terhadap IPM. Pemerintah baik pusat atau daerah diharapkan mampu meningkatkan pembangunan manusia di segala sektor bidang terutama kesehatan, pendidikan dan ekonomi.
\end{abstract}

Kata kunci: regresi ordinal, indeks pembangunan manusia, model logit 


\section{PENDAHULUAN}

Proses perubahan menuju sesuatu hal yang lebih baik dilakukan dengan berbagai upaya pembangunan (Abdoellah, 2016). Setiap daerah tentu melakukan upaya pembangunan yang bertujuan untuk meningkatkan kualitas kehidupan masyarakat sehingga pada akhirnya akan mewujudkan masyarakat yang adil, makmur dan sejahtera. Menurut Masruroh \& Subekti (2016), pembangunan merupakan strategi untuk memajukan kehidupan bangsa dan negara dengan cara menciptakan sarana dan prasarana yang baru sehingga dapat digunakan bagi kepentingan masyarakat. Selain itu dapat pula dilakukan pengembangan sarana dan prasarana yang sudah ada sebelumnya untuk mewujudkan suatu tujuan.

Upaya pembangunan di daerah membutuhkan Sumber Daya Manusia (SDM) sebagai faktor sentral pembangunan dimana SDM dijadikan sebagai agen pembangunan. Oleh sebab itu, pentingnya SDM harus diikuti pula dengan adanya upaya pembangunan manusia.

Konsep antara pembangunan dan pembangunan manusia memang cukup berbeda. Pembangunan lebih fokus pada pemenuhan kebutuhan hal-hal yang mendasar bagi masyarakat, kehidupan yang sejahtera bagi masyarakat, pembangunan dan pembentukan sumber daya manusia, pembentukan modal manusia dan pertumbuhan ekonomi. Sedangkan pembangunan manusia lebih fokus pada pilihan masyarakat tentang bagaimana memiliki kehidupan yang bebas dan bermartabat dimana mencakup kebebasan berpolitik, ketenagakerjaan, perdagangan, pertumbuhan ekonomi, nilai-nilai kultural dan gender (Trianggara, Rahmawati dan Yasin, 2016).

Setiap daerah tentu melakukan upaya pembangunan manusia yang berbeda. Hal itu terletak pada program kesehatan, pendidikan dan ekonomi yang dilaksanakan untuk meningkatkan nilai IPM. Oleh sebab itu untuk mengukur bagaimana tingkatan pembangunan manusia di suatu daerah digunakan salah satu ukuran indeks yakni Indeks Pembangunan Manusia atau biasa disingkat IPM.
BPS (2018) menyebutkan bahwa IPM merupakan ukuran indeks yang dipergunakan untuk melakukan pengukuran terhadap hasil kinerja upaya pembangunan manusia berdasarkan berbagai elemen dasar yang menjadi pondasi pembentukan kualitas hidup manusia. IPM dibentuk dari tiga dimensi dasar digunakan untuk ukuran kualitas hidup manusia yakni dimensi umur panjang dan hidup sehat, dimensi pengetahuan dan dimensi standar hidup layak. Dimensi pertama diukur berdasarkan Angka Harapan Hidup (AHH) ketika seseorang dilahirkan. Dimensi kedua terkait pengetahuan dihitung atas dasar nilai rata-rata lama sekolah serta harapan lama sekolah pada tiap wilayah tertentu. Dimensi ketiga dihitung berdasarkan Produk Nasional Bruto (PNB) per kapita yang dihasilkan. Ketiga dimensi dasar di atas dibangun berbasis sektor pembentuk IPM yakni sektor kesehatan, sektor pendidikan dan sektor ekonomi.

IPM merupakan ukuran yang dipergunakan untuk mengetahui bagaimana hasil kinerja upaya pembangunan di berbagai daerah yang memiliki dimensi yang sangat luas. IPM dapat pula menunjukkan bagaimana tingkat kualitas masyarakat di suatu wilayah untuk sektor kesehatan, sektor pendidikan dan sektor ekonomi (Melliana \& Zain, 2013).

BPS menyebutkan dalam hasil publikasi Indeks Pembangunan Manusia 2015, nilai IPM dapat dikelompokkan berdasarkan status pembangunan manusia yang terdiri dari empat kategori status yakni rendah (IPM $<60$ ), sedang $(60 \leq$ IPM $<70)$, tinggi $(70 \leq$ IPM $<80)$ dan sangat tinggi (IPM $\geq 80$ ) (BPS, 2016).

Tahun 2017, Jawa Timur mempunyai jumlah penduduk mencapai 39 juta jiwa lebih. Capaian tersebut menjadikan Provinsi Jawa Timur di peringkat kedua provinsi terbesar di Indonesia sesudah Provinsi Jawa Barat (BPS, 2018). IPM Provinsi Jawa Timur untuk tahun 2017 sebesar 70,27 dimana masuk dalam kategori tinggi berdasarkan pengkategorian dari BPS. Akan tetapi, nilai IPM Provinsi Jawa Timur ada pada lingkup dengan nilai di bawah rata-rata IPM Indonesia yang memiliki nilai 70,81 dengan besar selisih antara keduanya yaitu 0,54 . 
Upaya untuk membangun sumber daya manusia Provinsi Jawa Timur juga masih belum adanya pemerataan. Selain itu, adanya rentang yang cukup tinggi menunjukkan besarnya masalah kesenjangan diantara berbagai daerah. Hal ini bisa diketahui dari nilai IPM Kota Surabaya yang memiliki nilai sebesar 81,07 dimana menjadi IPM tertinggi di Provinsi Jawa Timur. Namun sebaliknya, masih ada nilai IPM yang memiliki rentang cukup jauh dari rata-rata nilai IPM Jawa Timur yaitu Kabupaten Sampang yang hanya memiliki nilai sebesar 59,90 dimana menjadi IPM terendah. Oleh sebab itu diperlukan penelitian untuk mengidentifikasi faktor yang menjadi pengaruh bagi IPM Jawa Timur (BPS Provinsi Jawa Timur, 2018).

Penelitian sebelumnya banyak faktor diduga menjadi pengaruh bagi Indeks Pembangunan Manusia baik di sektor bidang kesehatan, sektor pendidikan maupun sektor ekonomi. Destilunna \& Zain (2015), melakukan penelitian tentang pengaruh variabel jumlah sarana kesehatan, angka partisipasi SMA, rasio guru-siswa SMP dan MTs, angka partisipasi SMP, rasio sekolahmurid SMP dan MTs, PDRB UMKM, tingkat pengangguran terbuka dan kepadatan penduduk terhadap IPM. Penelitian tersebut memberikan hasil dengan membuktikan bahwa variabel independen yang signifikan memiliki pengaruh bagi IPM yaitu angka partisipasi SMA, angka partisipasi SMP, rasio guru-siswa SMP dan MTs, PDRB UMKM, tingkat pengangguran terbuka serta kepadatan penduduk.

Menurut teori H.L. Blum dalam Indeks Pembangunan Manusia 2015, tingkat kesehatan masyarakat dapat diukur dari 4 faktor salah satunya adalah perilaku kesehatan. Dimana perilaku kesehatan menyumbang sebesar 30\% perhitungan status/derajat kesehatan masyarakat. Contoh dari perilaku kesehatan yaitu Perilaku Hidup Bersih dan Sehat dimana biasa disebut PHBS. Dalam hal ini, PHBS adalah perilaku kesehatan seseorang dimana dilakukan dengan keadaan sadar diri sendiri. Ketika seseorang itu mampu melakukan perilaku kesehatan dengan baik maka seluruh elemen keluarga mampu membantu dirinya sendiri pada sektor kesehatan. Selain itu mampu memberikan kontribusi secara nyata dalam upaya-upaya kesehatan di tengah masyarakat (Husna, 2018).

Tujuan penelitian ini yaitu untuk melakukan identifikasi faktor yang menjadi pengaruh bagi IPM Jawa Timur tahun 2017. Variabel dependen yang dipergunakan yakni nilai IPM setiap kabupaten/kota yang dikategorikan atas dasar status pembangunan manusia. Sedangkan variabel independen yang dipergunakan yaitu persentase rumah tangga berperilaku hidup bersih dan sehat, rasio murid-guru (SMA) dan tingkat pengangguran terbuka.

Analisis data untuk mengidentifikasi faktor yang menjadi pengaruh bagi IPM untuk penelitian ini memakai pendekatan regresi ordinal model logit. Regresi ordinal merupakan metode statistika secara khusus dipakai untuk melakukan analisis variabel dependen dengan data berskala kategorik bertingkat. Sedangkan variabel independen dapat menggunakan skala data kategorik maupun numerik.

Regresi ordinal memiliki lima fungsi tautan (link function) yang dapat dipilih sebagai model antara lain cauchit (inverse cauchy), complementary log-log, logit, negative log-log dan probit. Pada penelitian ini model logit dipilih karena didasarkan pada kesesuaian distribusi data yang ada. Selain itu juga didasarkan pada uji asumsi yang disyaratkan yaitu asumsi garis paralel lines. Nilai dari signifikansi uji asumsi tersebut harus lebih besar dari 0,05 .

Model logit merupakan model yang paling banyak digunakan dalam analisis regresi ordinal. Model logit lebih disukai daripada yang lainnya karena sifat kesederhanaan dalam interpretasi hasil analisis (Begg, 2009).

Bentuk persamaan dari model logit kumulatif bagi dependen ordinal dengan $\mathrm{k}$ kategori yaitu:

$$
\operatorname{Logit}\left[c_{j}\right]=\log \left[\frac{c_{j}}{1-c_{j}}\right]=\theta_{j}+\beta^{T} x
$$

dengan $\pi_{j}$ merupakan peluang kategori dependen ke-j, $C_{j}=[\mathrm{P}(\mathrm{Y} \leq j)]$ merupakan peluang kumulatif kategori dependen ke-j $=\pi_{1}+\pi_{2}+\ldots+\pi_{j}$. $\theta_{j}$ merupakan konstanta $(j=1,2, \ldots, k-1)$. Sedangkan $\beta^{T}=\left(\beta_{1}, \beta_{2}, \ldots, \beta_{p}\right)$ merupakan parameter koefisien yang dipergunakan untuk menunjukkan pengaruh $X$ terhadap model logit 
$C_{j}$ untuk variabel dependen $(y)$ pada tingkatan kategori kurang dari atau sama dengan $j$.

$X^{T}=\left(X_{1}, X_{2}, \ldots, X_{p}\right)$ merupakan variabel independen.

Variabel independen pada persamaan model logit kumulatif dapat berupa variabel kontinu, kategori atau keduanya maka bentuk persamaan diubah ke dalam bentuk eksponensial (Raharjanti \& Widiharih, 2005). Bentuk persamaan akan diperoleh sebagai berikut:

$$
c_{j}=[P(Y \leq j)]=\frac{e^{\theta_{j}+\beta^{T} x}}{1+e^{\theta_{j}+\beta^{T} x}}
$$

Regresi ordinal sendiri tidak membutuhkan asumsi-asumsi klasik seperti uji normalitas, uji homogenitas dan varians konstan. Namun, regresi ordinal membutuhkan asumsi garis paralel atau biasa disebut uji paralel lines yang digunakan untuk menyeleksi atau memilih model yang terbaik. Selain itu dapat pula digunakan untuk mengetahui kesesuaian fungsi tautan (link function) yang dipilih. Nilai dari signifikansi uji paralel lines harus lebih besar dari 0,05.

\section{METODE PENELITIAN}

Penelitian tentang identifikasi faktor yang menjadi pengaruh bagi IPM Jawa Timur tahun 2017 adalah penelitian yang memiliki sifat nonreaktif dengan memakai data-data sekunder. Penelitian ini menggunakan data sekunder dari hasil publikasi oleh BPS dan Dinas Kesehatan Provinsi Jawa Timur tahun 2017.

Penelitian dilakukan hanya mengambil data sekunder dari hasil publikasi pada situs resmi online BPS dan Dinas Kesehatan Provinsi Jawa Timur. Populasi penelitian yakni semua kabupaten/kota. Total unit analisis penelitian sebanyak 38 daerah dimana terdapat 29 kabupaten dan 9 kota.

Variabel penelitian terdiri dari dua variabel yakni variabel independen dan variabel dependen. Variabel dependen penelitian yaitu IPM yang dikategorikan berdasarkan status pembangunan manusia. Sehingga dalam hal ini, variabel dependen memiliki skala data ordinal. Variabel independen penelitian ini yaitu persentase rumah tangga berperilaku hidup bersih dan sehat, rasio murid-guru (tingkat SMA) dan tingkat pengangguran terbuka dengan skala data rasio. Teknik analisis data yang dipergunakan untuk penelitian yaitu pendekatan uji regresi ordinal model logit.

\section{HASIL PENELITIAN}

Faktor yang menjadi pengaruh bagi IPM Jawa Timur tahun 2017 dianalisis memakai uji regresi ordinal model logit. Data yang dipakai berasal dari situs resmi online BPS dan Profil Kesehatan Jawa Timur tahun 2017.

Variabel yang diteliti meliputi persentase rumah tangga berperilaku hidup bersih dan sehat $\left(\mathrm{X}_{1}\right)$, rasio murid-guru tingkat SMA $\left(\mathrm{X}_{2}\right)$ dan tingkat pengangguran terbuka $\left(\mathrm{X}_{3}\right)$ terhadap IPM $(Y)$. Variabel dependen IPM memiliki skala data ordinal dengan empat kategori (sangat tinggi, tinggi, sedang dan rendah). Variabel indepeden yaitu persentase rumah tangga berperilaku hidup bersih dan sehat, rasio murid-guru (tingkat SMA) dan tingkat pengangguran terbuka memiliki skala data rasio.

Berdasarkan tabel 1, hasil nilai deskriptif memperlihatkan apabila semua variabel independen mempunyai nilai standar deviasi lebih rendah daripada nilai rata-rata (mean). Dapat disimpulkan bila keragaman data pada semua variabel independen cenderung besar.

Berdasarkan Tabel 2 diketahui bahwa sebagian besar IPM Jawa Timur tahun 2017 masuk pada kategori sedang 47,4\%. Kemudian

Tabel 1. Hasil Nilai Deskriptif

\begin{tabular}{ccc}
\hline Variabel & Mean & $\begin{array}{c}\text { Std. } \\
\text { Deviation }\end{array}$ \\
\hline $\mathrm{X}_{1}$ & 54,005 & 15,1828 \\
$\mathrm{X}_{2}$ & 11,4042 & 3,73860 \\
$\mathrm{X}_{3}$ & 3,7637 & 1,30682 \\
\hline
\end{tabular}

Tabel 2. Hasil Analisis IPM

\begin{tabular}{ccc}
\hline Kategori IPM & Frekuensi & Persentase \\
\hline Rendah & 1 & $2,6 \%$ \\
Sedang & 18 & $47,4 \%$ \\
Tinggi & 16 & $42,1 \%$ \\
Sangat Tinggi & 3 & $7,9 \%$ \\
\hline
\end{tabular}


sebesar 42,1\% IPM memasuki kedalam kategori tinggi. Sedangkan IPM masuk dalam kategori sangat tinggi hanya sebesar $7,9 \%$. Sisanya hanya sebesar 2,6\% IPM masuk dalam kategori rendah.

Regresi ordinal dalam penelitian ini digunakan untuk melakukan identifikasi faktor yang mempengaruhi IPM Jawa Timur tahun 2017 dimana variabel dependen IPM memiliki lebih dari dua kategori yaitu kategori IPM rendah, kategori IPM sedang, kategori IPM tinggi dan kategori IPM sangat tinggi. Sebelum dilakukan hasil analisis uji pengaruh dengan regresi ordinal maka akan dijelaskan mengenai asumsi yang mendasarinya:

\section{Uji Parallel Lines}

Uji parallel lines merupakan salah satu asumsi yang harus terpenuhi dalam analisis regresi ordinal. Uji parallel lines dipergunakan untuk melakukan pengujian terhadap seluruh kategori apakah mempunyai parameter yang sama ataukah berbeda. Uji ini juga dilakukan untuk mengetahui apakah model fungsi tautan (link function) yang digunakan sesuai ataupun tidak sesuai (Ghozali, 2009). Hasil uji parallel lines disajikan dalam Tabel 3.

Berdasarkan hasil tabel uji parallel lines, model fungsi tautan (link function) bisa dikatakan sesuai apabila nilai signifikansi lebih besar daripada 0,05. Tabel 3 memperlihatkan apabila nilai signifikansi yang diperoleh sebesar 0,120 dimana lebih besar daripada 0,05 . Hasilnya menunjukkan pemilihan model fungsi tautan (link function) logit adalah tepat.

\section{Uji Keberartian Model}

Uji keberartian model atau overall fit model dilakukan dengan membandingkan model tanpa variabel independen dan model dengan variabel independen. Hasil uji keberartian model disajikan dalam Tabel 4. Nilai -2 log likelihood pada Tabel 4 digunakan untuk menilai kesesuaian model pada uji regresi ordinal. Model dikatakan fit/ sesuai apabila adanya penurunan pada nilai $-2 \log$ likelihood dan nilai signifikansi yang lebih kecil daripada nilai $\alpha$. Tabel 4 memperlihatkan bila nilai signifikansi yang dihasilkan sebesar 0,004
Tabel 3. Uji Parallel Lines

\begin{tabular}{ccc}
\hline Model & $\mathbf{- 2}$ Log Likelihood & Sig. \\
\hline Null Hypothesis & 66,118 & \\
General & 61,874 & 0,120 \\
\hline
\end{tabular}

Tabel 4. Uji Keberartian Model

\begin{tabular}{ccc}
\hline Model & $\mathbf{- 2}$ Log Likelihood & Sig. \\
\hline Intercept Only & 74,316 & \\
Final & 66,118 & 0,004 \\
\hline
\end{tabular}

Tabel 5. Uji Kebaikan Model (Goodness of Fit)

\begin{tabular}{ccc}
\hline & Chi-Square & Sig. \\
\hline Pearson & 78,322 & 0,972 \\
Deviance & 63,346 & 0,999 \\
\hline
\end{tabular}

dimana lebih kecil dari tingkat keterandalan yang dipergunakan $(\alpha=0,05)$. Sedangkan nilai -2 log likelihood mengalami penurunan sebesar 8,198 yang merupakan nilai chi-square. Kedua hasil tersebut mengindikasikan bahwa model adalah sesuai (fit).

\section{Uji Kebaikan Model (Goodness of Fit)}

Pengujian kebaikan model (Goodness of Fit) adalah sebuah uji yang dipergunakan untuk melihat apakah regresi ordinal model logit yang dihasilkan layak atau tidak layak untuk dipakai. Hasil pengujian kebaikan model (Goodness of Fit) disajikan dalam Tabel 5.

Uji kebaikan model menggunakan Pearson dan Deviance. Model yang dihasilkan dianggap sesuai jika nilai signifikansi yang dihasilkan lebih besar dari nilai $\alpha(0,05)$. Dari Tabel 5, nilai signifikansi dari Pearson $(0,972)$ dan Deviance $(0,999)$ lebih besar daripada 0,05 yang menandakan bahwa model adalah sesuai. Kesimpulannya, model logit yang dibangun untuk penelitian ini baik.

\section{Koefisiensi Determinasi Model}

Besarnya nilai koefisiensi determinasi ditunjukkan oleh nilai Pseudo R-Square yaitu Cox and Snell, Nagelkerke dan McFadden. Hasil koefisiensi determinasi model dalam penelitian ini disajikan dalam Tabel 6. 
Tabel 6. Koefisiensi Determinasi Model (Pseudo R-Square)

\begin{tabular}{cc}
\hline Cox and Snell & 0,194 \\
Nagelkerke & 0,223 \\
McFadden & 0,106 \\
\hline
\end{tabular}

Berdasarkan hasil Tabel 6 menunjukkan besaran koefisiensi determinasi model Cox and Snell sebesar 0,194; Nagelkerke sebesar 0,223 dan McFadden sebesar 0,106. Koefisiensi determinasi model Nagelkerke sebesar 0,223 atau $22,3 \%$ berarti variabel independen yaitu persentase rumah tangga berperilaku hidup bersih dan sehat, rasio murid-guru (tingkat SMA) dan tingkat pengangguran terbuka di kabupaten/kota Provinsi Jawa Timur tahun 2017 mempengaruhi Indeks Pembangunan Manusia (IPM) sebesar $22,3 \%$. Sedangkan $77,7 \%$ dijelaskan oleh faktor-faktor lain yang tidak termasuk kedalam pengujian model.

\section{Hasil Estimasi Regresi Ordinal Model Logit}

Hasil estimasi parameter dari regresi ordinal model logit digunakan untuk membuktikan apakah hipotesis ditolak atau hipotesis diterima pada tampilan output variable in equation (Iban \& Indriani, 2019). Hal yang menjadi dasar pertimbangan pengambilan keputusan dalam menentukan suatu variabel signifikan atau tidak signifikan yang harus dibandingkan dengan tingkat signifikan yang telah ditetapkan yaitu sebesar 0,05 . Apabila suatu variabel memiliki signifikansi lebih besar daripada 0,05 hasilnya variabel tersebut tidak signifikan yang memiliki arti Ho diterima dan Ha ditolak. Akan tetapi, apabila suatu variabel memiliki signifikansi lebih kecil dari 0,05 maka variabel itu signifikan yang berarti $\mathrm{HO}$ ditolak dan Ha diterima.

Berdasarkan hasil tabel 7 , pengujian hipotesis adalah Tidak terdapat pengaruh persentase rumah tangga berperilaku hidup bersih dan sehat terhadap IPM; Tidak terdapat pengaruh rasio murid-guru (tingkat SMA) terhadap IPM; Terdapat pengaruh tingkat pengangguran terbuka terhadap IPM. Variabel ini memiliki koefisiensi positif sebesar 0,790 dengan tingkat signifikansi yaitu 0,006 serta nilai statistik Wald sebesar 7,506 .
Tabel 7. Hasil Estimasi Parameter

\begin{tabular}{lcc}
\hline & Estimate & Sig. \\
\hline Threshold & & \\
IPM Rendah & $-1,097$ & 0,403 \\
IPM Sedang & 2,921 & 0,010 \\
$\quad$ IPM Tinggi & 5,767 & 0,000 \\
$\begin{array}{l}\text { Location } \\
\mathrm{X}_{3}\end{array}$ & 0,790 & 0,006 \\
\hline
\end{tabular}

Hasil estimasi parameter dapat dibentuk model logit untuk IPM berdasarkan status pembangunan manusia. Persamaan regresi yang dihasilkan dapat dijelaskan sebagai berikut:

Logit $c 1=-1,097+0,790 \times 3$

$\log i t(c 1+c 2)=2,921+0,790 \times 3$

Logit $(c 1+c 2+c 3)=5,767+0,790 \times 3$

Dimana $\mathrm{c} 1=$ probabilitas kategori IPM rendah, $\mathrm{c} 2=$ probabilitas kategori IPM sedang dan $\mathrm{c} 3$ = probabilitas kategori IPM tinggi.

Dari persamaan pengaruh variabel tingkat pengangguran terbuka terhadap IPM diinterpretasikan sebagai berikut:

Jika tingkat pengangguran terbuka $=1$ dan variable lain dianggap 0 (konstan) maka:

$c 1=\frac{\exp (-1,097+0,790)}{1+\exp (-1,097+0,790)}=0,4238$

$c 1+c 2=\frac{\exp (2,921+0,790)}{1+\exp (2,921+0,790)}=0,9761$

$c 1+c 2+c 3=\frac{\exp (5,767+0,790)}{1+\exp (5,767+0,790)}=0,9986$

Berdasarkan hasil tersebut dapat disimpulkan bahwa untuk tiap kenaikan tingkat pengangguran terbuka sebesar $1 \%$ dapat menaikkan probabilitas IPM masuk dalam kategori rendah sebesar 0,4238; meningkatkan probabilitas indeks pembangunan manusia masuk dalam kategori sedang sebesar 0,9761 dan meningkatkan probabilitas indeks pembangunan manusia masuk dalam kategori tinggi sebesar 0,9986. Dengan demikian dapat disimpulkan bahwa setiap kenaikan tingkat pengangguran terbuka mampu meningkatkan nilai IPM. 


\section{PEMBAHASAN}

Luas Jawa Timur sebesar $47.799,75 \mathrm{~km}^{2}$ terdiri dari 38 daerah dimana terdapat rincian 29 kabupaten dan 9 kota. 29 kabupaten meliputi Bangkalan, Bojonegoro, Bondowoso, Blitar, Banyuwangi, Gresik, Jombang, Jember, Kediri, Lamongan, Lumajang, Magetan, Madiun, Mojokerto, Malang, Ngawi, Nganjuk, Pamekasan, Pasuruan, Probolinggo, Ponorogo, Pacitan, Sumenep, Sampang, Sidoarjo, Situbondo, Tuban, Tulungagung dan Trenggalek. Sedangkan 9 kota meliputi Mojokerto, Probolinggo, Pasuruan, Batu, Malang, Blitar, Kediri, Madiun dan Surabaya.

IPM adalah ukuran indikator yang dipergunakan untuk melakukan pengukuran terhadap pencapaian upaya pembangunan manusia berdasarkan berbagai elemen dasar yang membentuk kualitas hidup manusia. IPM dibentuk dari tiga dimensi dasar yang dibentuk berdasarkan sektor kesehatan, sektor pendidikan dan sektor ekonomi. Berdasarkan hasil penelitian didapatkan faktor yang menjadi pengaruh bagi IPM.

Kesehatan menjadi hak asasi manusia dimana undang-undang dasar akan menjamin hak kesehatan tersebut. Selain itu kesehatan juga merupakan investasi sumber daya manusia bagi suatu daerah/wilayah serta bagi sebuah negara. Dalam hal ini, kesehatan mempunyai suatu pengaruh yang sangat besar untuk Indeks Pembangunan Manusia. Adanya pemeliharaan kesehatan masyarakat dapat memacu dan meningkatkan adanya produktifitas kerja masyarakat. Pada akhirnya mampu menaikkan tingkat kemakmuran dan kesejahteraan masyarakat itu sendiri. Oleh sebab itu menjadi sebuah kewajiban untuk seluruh elemen yang ada di tengah masyarakat untuk melindungi, meningkatkan dan memelihara upaya kesehatan demi kemakmuran dan kesejahteraan seluruh masyarakat (Husna, 2018).

Salah satu komponen dalam indeks kesehatan adalah persentase rumah tangga berperilaku hidup bersih dan sehat. Menurut Depkes RI (2009), PHBS yaitu seluruh perilaku kesehatan seseorang yang dilakukan atas keadaan sadar diri sendiri. Pada akhirnya seluruh elemen keluarga mampu memberikan pertolongan bagi dirinya sendiri pada sektor kesehatan. Selain itu mampu memberikan kontribusi secara nyata untuk upaya-upaya kesehatan di tengah masyarakat.

Hasil penelitian dengan menggunakan analisis regresi ordinal model logit menunjukkan persentase rumah tangga berperilaku hidup bersih dan sehat tidak terdapat pengaruh signifikan terhadap IPM yang dikelompokkan berdasarkan status pembangunan manusia.

Rasio murid-guru adalah ukuran perbandingan antara jumlah murid dengan jumlah guru untuk tingkatan pendidikan tertentu. Rasio murid-guru dijadikan sebagai salah satu indikator pendidikan. BPS Provinsi Jawa Timur (2018) menganalisis data dengan memperlihatkan bahwa rasio murid-guru tingkat SMA sebesar 11,98. Rasio murid-guru tingkat SMA terendah adalah Kota Madiun sebesar 3,84; sedangkan yang tertinggi adalah Kabupaten Pasuruan sebesar 20,79 .

Hasil penelitian dengan menggunakan analisis regresi ordinal model logit menunjukkan bila rasio murid-guru tingkat SMA tidak terdapat pengaruh signifikan terhadap IPM yang dikelompokkan berdasarkan status pembangunan manusia. Sejalan dengan penelitian Putra \& Ratnasari (2015) yang membuktikan bahwa rasio guru-siswa (SMA) bukanlah faktor yang menjadi pengaruh bagi IPM di Provinsi Jawa Timur ( $p=$ 0,3869).

BPS menyatakan bahwa Tingkat Pengangguran Terbuka (TPT) diartikan sebagai besarnya persentase jumlah penduduk yang menganggur terhadap jumlah penduduk sebagai bagian dari angkatan kerja. TPT merupakan sebuah indikasi dari besaran persentase penduduk angkatan kerja yang masuk kedalam lingkup pengangguran.

Tingkat pengangguran yang tinggi menjadi masalah ekonomi bagi suatu wilayah khususnya terkait masalah kemiskinan. Karena pada dasarnya kemiskinan dan pengangguran saling berpengaruh antara satu dengan yang lain (Chalid \& Yusbar, 2014). Adanya pengangguran akan mengurangi penghasilan seseorang sehingga dapat mengurangi pula tingkatan kesejahteraan seseorang. 
Hasil analisis regresi ordinal model logit memperlihatkan bila tingkat pengangguran terbuka terdapat pengaruh signifikan terhadap IPM. Sejalan dengan penelitian Destilunna \& Zain (2015), dimana tingkat pengangguran terbuka mempunyai pengaruh signifikan terhadap IPM Jawa Timur dengan $p$ value sebesar 0,0035 .

\section{SIMPULAN DAN SARAN}

\section{Simpulan}

Hasil analisis regresi ordinal model logit didapatkan faktor yang menjadi pengaruh bagi IPM Provinsi Jawa Timur adalah tingkat pengangguran terbuka dengan $p$ value sebesar 0,006 dan $\beta$ sebesar 0,790 .

Tiap kenaikan tingkat pengangguran terbuka sebesar 1\% dapat menaikkan probabilitas IPM masuk dalam kategori rendah sebesar 0,4238; meningkatkan probabilitas indeks pembangunan manusia masuk dalam kategori sedang sebesar 0,9761 dan meningkatkan probabilitas indeks pembangunan manusia masuk dalam kategori tinggi sebesar 0,9986. Dengan demikian dapat disimpulkan bahwa setiap kenaikan tingkat pengangguran terbuka mampu meningkatkan nilai IPM.

\section{Saran}

Pemerintah baik pusat dan daerah perlu melakukan peningkatan IPM Jawa Timur melalui upaya di bidang ekonomi yaitu menurunkan tingkat pengangguran terbuka dengan cara memperkuat pelatihan vokasi dan life skill di semua tingkat untuk mengembangkan angkatan kerja yang fleksibel dan terlatih dengan atribut personal, ketrampilan dan kompetensi dasar yang memadai. Selain itu diperlukan peningkatan penciptaan lapangan pekerjaan. Hal ini dilakukan sebagai upaya pemerataan pembangunan manusia sehingga pada akhirnya dapat menaikkan IPM Jawa Timur.

\section{DAFTAR PUSTAKA}

Abdoellah, O., 2016. Pembangunan Berkelanjutan di Indonesia: Di Persimpangan Jalan. Jakarta: PT Gramedia Pustaka Utama.
Begg, M.D., 2009. An Introduction to Categorical Data Analysis (2nd edn). Alan Agresti, John Wiley \& Sons, Inc., Hoboken, New Jersey, 2007. No. of Pages: 400. Price: \$100.95. ISBN: 978-0-471-22618-5. Statistics in Medicine, 28(11), p.1643.

BPS, 2016. Indeks Pembangunan Manusia 2015. Jakarta: Badan Pusat Statistik.

BPS, 2018. Konsep Indeks Pembangunan Manusia. [online] Available at: $<$ https://www. bps.go.id/subject/26/indeks-pembangunanmanusia.html\#subjekViewTab1> [Accessed 9 Apr. 2019].

BPS Provinsi Jawa Timur, 2018. Indeks Pembangunan Manusia Jawa Timur Tahun 2017. Surabaya: Badan Pusat Statistik Provinsi Jawa Timur.

Chalid, N., Yusbar, Y., 2014. Pengaruh Tingkat Kemiskinan dan Tingkat Pengangguran, Upah Minimun Kabupaten/Kota dan Laju Pertumbuhan Ekonomi Terhadap Indeks Pembangunan Manusia di Provinsi Riau. Jurnal Ekonomi, 22(2), pp.1-12.

Depkes RI, 2009. Rumah Tangga Sehat dengan Perilaku Hidup Bersih dan Sehat. Jakarta: Departemen Kesehatan Republik Indonesia.

Destilunna, F.G., Zain, I., 2015. Pengaruh dan Pemetaan Pendidikan, Kesehatan serta UMKM terhadap Indeks Pembangunan Manusia di Jawa Timur Menggunakan Regresi Panel dan Biplot. Jurnal Sains dan Seni ITS, 4(2), pp.292-298.

Ghozali, I., 2009. Analisis Multivariate Lanjutan dengan Program SPSS. Semarang: Badan Penerbit Universitas Diponegoro.

Husna, L., 2018. Analisa Faktor Prilaku Hidup Bersih dan Sehat (PHBS) di Wilayah Kerja Puskesmas Simpang IV Sipin Kota Jambi Tahun 2017. Jurnal Ilmiah Dikdaya, 8(2), pp.298-311.

Iban, M., Indriani, D., 2019. Analisis Regresi Ordinal Model Logit dan Probit untuk Memprediksi Faktor yang Mempengaruhi Bayi Berat Lahir Rendah. Jurnal Biometrika dan Kependudukan, 8(1), pp.62-71.

Masruroh, M., Subekti, R., 2016. Aplikasi Regresi Partial Least Square untuk Analisis Hubungan Faktor-Faktor yang Mempengaruhi Indeks Pembangunan Manusia di Kota Yogyakarta. Media Statistika, 9(2), pp.75-84. 
Melliana, A., Zain, I., 2013. Analisis Statistika Faktor yang Mempengaruhi Indeks Pembangunan Manusia di Kabupaten/Kota Provinsi Jawa Timur dengan Menggunakan Regresi Panel. Jurnal Sains dan Seni POMITS, 2(2), pp.2337-3520.

Putra, D.M., Ratnasari, V., 2015. Pemodelan Indeks Pembangunan Manusia (IPM) Provinsi Jawa Timur Dengan Menggunakan Metode Regresi Logistik Ridge. Jurnal Sains dan Seni ITS, 4(2), pp.175-180.
Raharjanti, R.P., Widiharih, T., 2005. Model Logit Kumulatif untuk Respon Ordinal. Jurnal Matematika, 8(3), pp.102-107.

Trianggara, N., Rahmawati, R., Yasin, H., 2016. Pemodelan Indeks Pembangunan Manusia Menggunakan Spatial Panel Fixed Effect (Studi Kasus: Indeks Pembangunan Manusia Propinsi Jawa Tengah Periode 2008-2013). Jurnal Gaussian, 5(1), pp.173-182. 